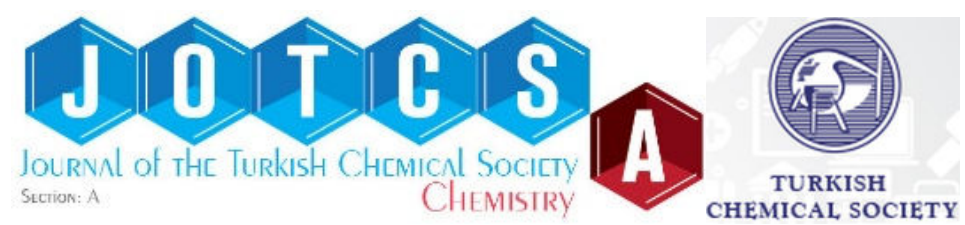

\title{
Anti-Diabetic Efficacy and Phytochemical Screening of Methanolic Leaf Extract of Pawpaw (Carica papaya) Grown in North Central Nigeria.
}

\author{
Ayorinde Victor Ogundele*1, Kabir Opeyemi Otun ${ }^{1}$, Abdulfatai Ajiboye ${ }^{1}$, Bolatito Eunice \\ Olanipekun ${ }^{1}$, and Rasheed Bolaji Ibrahim²
}

1. Chemistry unit, Department of Chemical, Geological and Physical Science, Kwara State University, P.M.B 1530, Malete, Nigeria.

2. Biochemistry unit, Department of Biosciences and Biotechnology, Kwara State University, P.M.B 1530, Malete, Nigeria.

\begin{abstract}
Carica papaya leaf samples (Green) were freshly harvested and dried for six consecutive days. The leaves were extracted with methanol; the resulting extracts were screened for the phytochemical constituents using a standard procedure. Phytochemical screening revealed the presence of bioactive compounds such as tannins, saponins, terpenoids, glycosides, and alkaloids. The in vitro anti-diabetic potential of the plant was also determined so as to justify the traditional usage of the plant in treating diabetes. The result of the present study confirmed that the methanolic extract of $C$. papaya leaves possess significant anti-diabetic activity in vitro, this shows that the leaves has the potential for the development of drugs in combating diabetes.
\end{abstract}

Keywords: Carica papaya leaves; phytochemical screening; bioactive substances; antidiabetic property; in-vitro analysis.

Submitted: August 09, 2016. Revised: September 23, 2016. Accepted: October 14, 2016.

Cite this: Ogundele A, Otun K, Ajiboye A, Olanipekun B, Ibrahim R. Anti-Diabetic Efficacy and Phytochemical Screening of Methanolic Leaf Extract of Pawpaw (Carica papaya) Grown in North Central Nigeria. JOTCSA. 2017;4(1):99-114.

DOI: $10.18596 /$ jotcsa.52813.

*Corresponding author. E-mail: vicshow2001@gmail.com. 


\section{INTRODUCTION}

Human beings have been plagued with diverse types of diseases such as HIV/AIDS, cancer, cholera, hepatitis, leprosy, measles, and diabetes among others. Diabetes mellitus is among the leading causes of death worldwide and it is prevalent in developing nations which may be partly due to the nature of the diets in this part of the world and other factors such as heredity and environmental factors. (1). This disease is caused by an unusual high concentration of sugar in the blood which might be a direct consequence of deficiency of insulin (2). The control or the cure of diabetes without side effects is a serious challenge militating against the development of anti-diabetic therapeutics over the centuries. Of core importance to the development of an anti-diabetic therapeutic is controlling hyperglycaemia, which is the milestone of diabetes and its complications. Thus, controlling excess sugar in the blood is the most crucial aim in reducing the risks associated with diabetes and its complications (3). One of the major means of treating the disease includes, but not limited to, insulin and various oral anti-diabetic agents such as sulfonylureas, biguanides and glinides. However, these agents are not devoid of adverse effects as such, there has been renewed search for hypoglycaemic agents with far lesser or no effect whatsoever.

Diabetes mellitus is an age-long disease and medicinal plant extracts have remained rich repository of therapeutically useful phytoconstituents and viable alternative in combating various diseases plaguing the mankind. There are some plants which possess bioactive compounds which have been reported to be used in combating diabetes worldwide and have been used in treating diabetes. Anti-hyperglycaemic properties of the plants are in direct relationship with their ability to restore the function of pancreatic tissues by causing an increase in insulin output or inhibit the intestinal absorption of glucose or to the facilitation of metabolites in insulin dependent processes (4).

Structures of some anti-diabetic compounds that have been successfully isolated from different plants are given below: 
<smiles>[R20]O[C@H]1O[C@H](CO)[C@@H](O)[C@H](O)[C@H]1O[C@H](C)/C=C/[C@@]1(O)C(C)=CC(=O)CC1(C)C</smiles><smiles>N[C@@H](Cn1cccn1)C(=O)O</smiles>

epigallocatechin gallate

beta-pyrazol-1-ylalanine

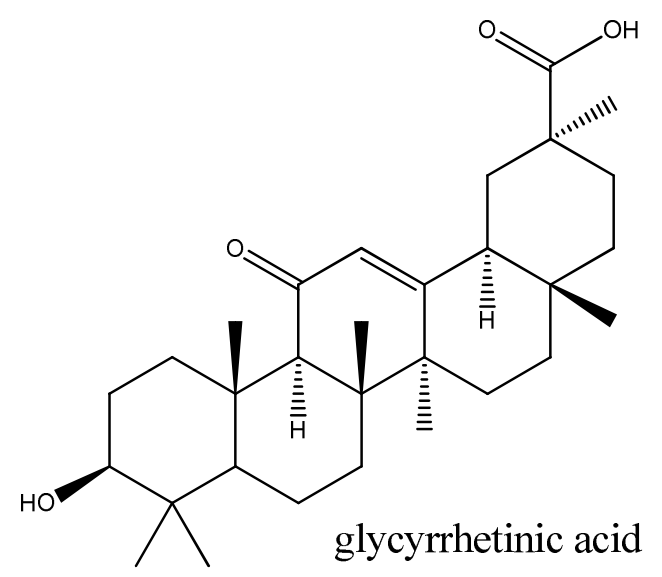<smiles>[2H]OC(=O)[C@@H](CCC(=C)C(C)C)C1CC[C@]2(C)C3=CC[C@]4(C)C(C)(C)[C@@H](O)CC[C@]4(C)C3=CC[C@]12C</smiles>

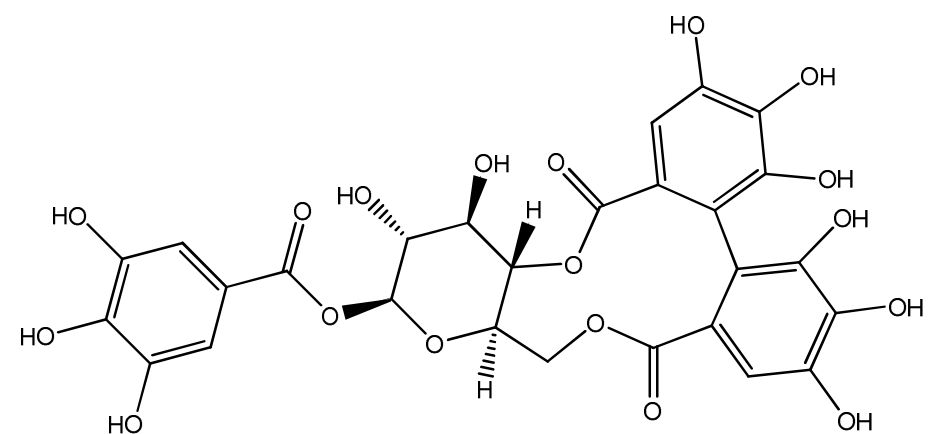

strictinin 


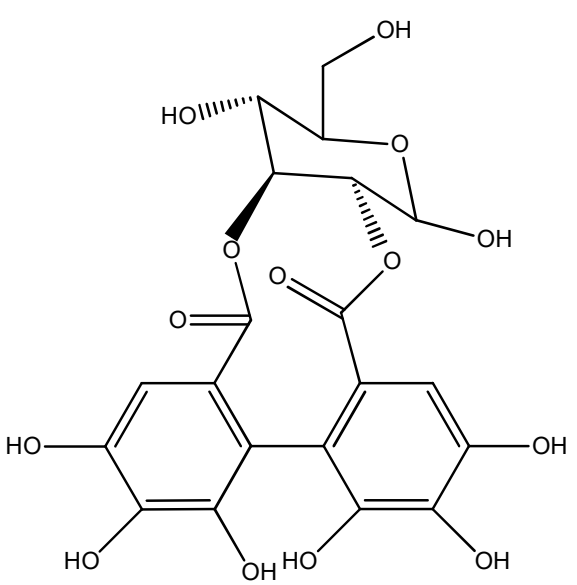

isostrictinin

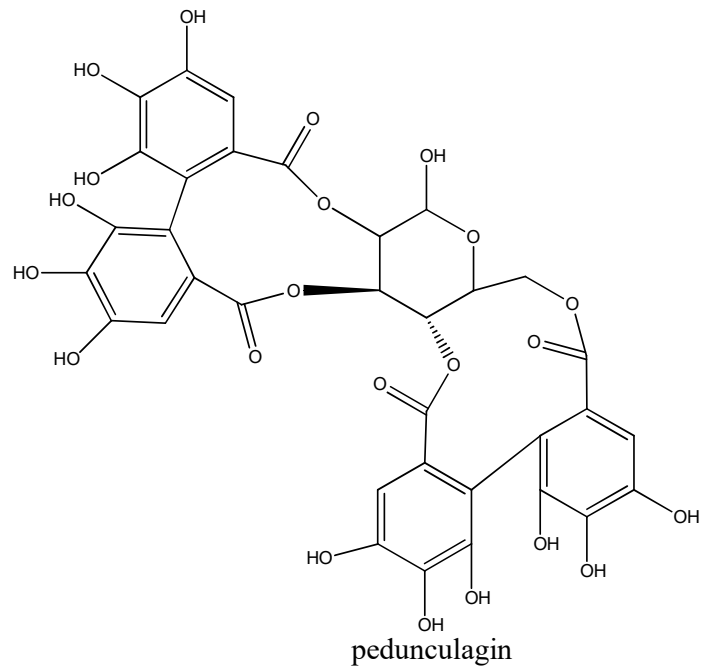<smiles>Oc1cc(O)c2c(c1)OC(c1ccc(O)c(O)c1)C(O)C2</smiles>

epicatechin

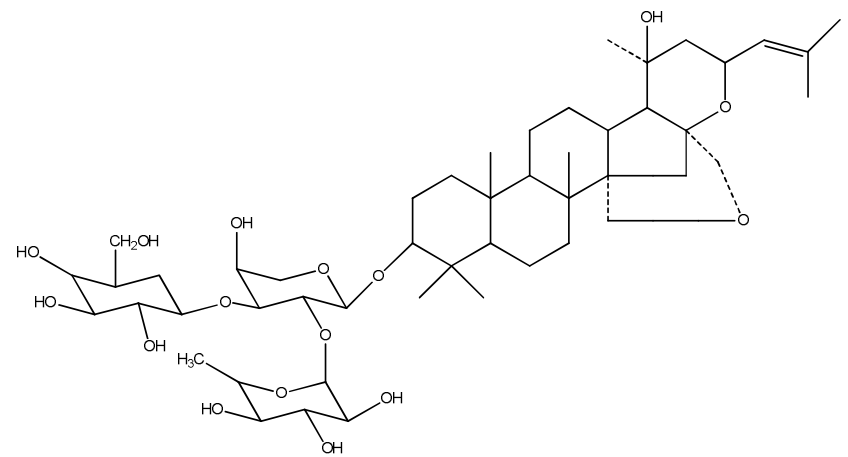

christinin-A

Plants are normally made use of in folk medicine to combat different ailments among which diabetes belong to, such plants include; Allium cepa (Onions), Cynodon dactylon, Clerodendron phlomoides, Cinnamomum tamala, Coccinia indica, Enicostemma littorale, Ficus bengalensig, Gymnema sylvestre leaves (Gurnar), Momordica charantia (Bitter melon), Pterocarpus marsupium, Syzygium cumini (6,7), Vernonia amygdalina, Pandanus amaryfollius (Pandan), Ocimum basilicum L. (Lamiaceae), Phyllanthus niruri L. (Euphoribiaceae), Viscum album L. (Viscaceae or Loranthaceae) (8), Allium sativum (Garlic), Aloe vera, Cinnamomum cassie, Catharanthus roseus (Madagascar periwinkle), Muurrayi komingii, Ocimum santum, panax ginseng, Trigonella foemum-graecum (Fenugreek), Pterocarpus marsupium (Indian kino) and Syzigium cumini (9-11). The isolated compounds from these plants are currently undergoing clinical trials so as to ascertain their efficacy and conformability to the standard.

Medicinal plants that have been confirmed to possess anti-diabetic properties in Nigeria areVinca major L, Azadirachta indica, Carica papaya, Gongronema latifolium, Securridaca langepedunculat, Sclerocarya birrea [CA. Rich], Momordica balsamina L, Hypoxis 
Ogundele et al., JOTCSA. 2017; 4(1): 99-114.

RESEARCH ARTICLE

hemerocallidea (Africa potato), Harpagophylum procumbens DC, Clauseria anisata (wild), Cissampelos capensis, Brachylaena discolour, (12-17).

Quite a number of researches have been conducted on various parts of Carica papaya family Caricaceae. The plant is home to various types of bioactive compounds (18). The leaves of Carica papaya are used traditionally to treat numerous ailments such as malaria, dengue, jaundice, immunomodulatory, and antiviral activity (19). Other diseases that have been reported to be controlled by Carica papaya traditionally in Nigeria includes; abdominal discomfort, pain, malaria, diabetes, obesity, infections, and oral drug poisonings. Adeneye and Olagunju, 2009 and Ahmad et al., 2011 reported the therapeutic potential of Carica papaya on dengue and malaria while Owoyele et al., 2008 confirmed the anti-inflammatory potency of the plant, similarly, Aruoma reported the effect of Carica papaya fruits and leaves on the sugar reducing tendency of the plant (20-23).

Despite the enormous work which have been done to probe the anti-diabetic potency of various parts of $C$. papaya over the world, report is scanty on the efficacy of the leaves of this plant in lowering the abnormally high blood sugar usually associated with diabetes hence, the present study aimed at investigating the phytochemical profile and also evaluate the in vitro anti-diabetic potency of C. papaya leaves.

\section{MATERIALS AND METHODS}

\section{Sample collection}

Green leaves of Carica papaya were collected from Islamic village in Ilorin, Ilorin West Local Government, Kwara State, Nigeria. The plant was authenticated at the herbarium of Plant and Environmental Biology Department, Kwara State University Malete, Nigeria.

\section{Preparation of Sample}

The leaves were dried under ambient conditions for six consecutive days and subsequently pulverized. A 70-gram-sample of the pulverized leaves was extracted with methanol for 72 hours and the resultant crude extract obtained was filtered. The crude extract was concentrated under reduced pressure using rotary evaporator to obtain a solvent-free methanol extract and stored in an air-tight bottle for further analyses. 
Ogundele et al., JOTCSA. 2017; 4(1): 99-114.

RESEARCH ARTICLE

\section{Phytochemical analysis}

The qualitative phytochemical tests were carried out to determine the presence and absence of various phytochemical constituents such as of alkaloids, saponins, glycosides, terpenoids, and tannins using the standard method (24).

\section{In vitro anti-diabetic activity test}

The Carica papaya leaf extract was subjected to non-enzymatic glycosylation of haemoglobin assay, and $\alpha$-amylase inhibition assay. Anti-diabetic efficacy of $C$. papaya was carried out by estimating the degree of non-enzymatic haemoglobin glycosylation, measured colorimetrically at $520 \mathrm{~nm}$. Glucose (2\%), haemoglobin (0.06\%) and gentamycin (0.02\%) solutions were prepared in phosphate buffer $0.01 \mathrm{M}$ and $\mathrm{pH}$ 7.4. $1 \mathrm{~mL}$ each of above solution was mixed. 1 $\mathrm{mL}$ of the concentrated extract was added to the mixture. It was incubated in dark at ambient condition for $72 \mathrm{hrs}$. The degree of glycosylation of haemoglobin was measured colorimetrically at $520 \mathrm{~nm}$. \% inhibition was calculated using standard literature procedure (34). $\alpha$-Tocopherol (Trolox) was used as a standard drug for assay (25).

\section{Alpha amylase inhibition assay}

A starch solution $(0.1 \% \mathrm{w} / \mathrm{v})$ was obtained by stirring $0.1 \mathrm{~g}$ of potato starch in $100 \mathrm{~mL}$ of 16 $\mathrm{mM}$ of sodium acetate buffer. The enzyme solution was prepared by mixing $27.5 \mathrm{mg}$ of alpha amylase in $100 \mathrm{~mL}$ of distilled water. The colorimetric reagent is prepared by mixing sodium potassium tartrate solution and 3,5-dinitrosalicylic acid solution at $96 \mathrm{mM}$. In alpha amylase inhibition method, $1 \mathrm{~mL}$ of substrate - potato starch ( $1 \% \mathrm{w} / \mathrm{v}), 1 \mathrm{~mL}$ of plant extract of four different concentrations $(40,60,80$, and $100 \mu \mathrm{g} / \mathrm{mL}), 1 \mathrm{~mL}$ of alpha amylase enzyme $(1 \%$ $\mathrm{w} / \mathrm{v})$ and $2 \mathrm{~mL}$ of acetate buffer $(0.1 \mathrm{M}, \mathrm{pH} 7.2)$ were added. Both control and plant extracts were added with starch solution and left to react with $\alpha$-amylase solution under alkaline conditions at $25^{\circ} \mathrm{C}$. The reaction was monitored for 3 minutes. The generation of maltose was quantified by the reduction of 3,5-dinitrosalicylic acid to 3-amino-5-nitrosalicylic acid. This reaction is detectable at $540 \mathrm{~nm}(26)$. 


\section{Glucose uptake in yeast cells}

Commercial baker's yeast was washed by repeated centrifugation (3000 g; 5 mins) with distilled water until the supernatant fluids were clean and $10 \%(\mathrm{v} / \mathrm{v})$ suspension was prepared in distilled water. Various concentrations of extracts (1-5 mg) were added to $1 \mathrm{~mL}$ of glucose solution (5, 10 and $25 \mathrm{mM}$ ) and incubated together for 10 mins at $37^{\circ} \mathrm{C}$. Reaction started by adding $100 \mathrm{~mL}$ of yeast suspension, vortexed and further incubated at $37^{\circ} \mathrm{C}$ for 60 mins. After that time, the tubes were centrifuged $(2500 \mathrm{~g}, 5 \mathrm{~min})$ and glucose was estimated in the supernatant. Metronidazole was taken as standard drug (27). The increase in the percentage of glucose uptake by yeast cells was calculated based on standard literature procedure.

\section{RESULTS AND DISCUSSION}

\section{Phytochemical analysis}

The result of the qualitative phytochemical screening (secondary metabolites) present in the methanolic extract of $C$. papaya leaves is presented in Table 1 . The screening revealed the presence of various bioactive constituents like polyphenol, tannins, saponins, terpenoids, flavonoids, glycosides and alkaloids. Anthocyanin was absent in the leaves studied. This result is in concordance with the reports (28-31). Various medicinal values of plants are functions of the phytochemicals that are present in such plant and may therefore be responsible for their anti-hyperglycemic properties.

Ayoola \& Adeyeye reported (30) that saponins, cardiac glycosides, and alkaloids are the major bioactive components present in the leaves of Carica papaya. The presence of saponins supports the fact that pawpaw leaf has cytotoxic effects (32). The presence of alkaloids in the leaves shows that this plant can be effective anti-malarial, since alkaloids consist of quinine, which is an anti-malarial drug (33). 
Table 1. Phytochemical screening of methanolic extracts of Carica papaya extract.

\begin{tabular}{|c|c|c|}
\hline & Phytochemical compounds & MTH/CP \\
\hline & Polyphenol \& Tannins & + \\
\hline & Flavonoids & + \\
\hline & Saponins & + \\
\hline & Terpenoids & + \\
\hline & Anthocyanins & - \\
\hline & $\frac{\text { Glycosides }}{\text { Alkaloids }}$ & $\begin{array}{l}++ \\
+\end{array}$ \\
\hline s: $+=$ trace amount, & $\begin{array}{c}\text { Carica papaya } \\
++=\text { strongly present, } \\
\text { C= }\end{array}$ & absent, \\
\hline
\end{tabular}

$\alpha$-amylase inhibitory effect of methanolic C.papaya extract

Alpha-amylase is a digestive enzyme found in the secretions of the intestinal mucosa, pancreas, and the saliva. It is responsible for the breakdown of a-1, 4-glycosidic bonds in starch. Thus, the catalytic activities of the enzyme (especially in the small intestine), increase the availability of glucose in the blood, since the $\mathrm{pH}$ of the intestine is around 6.9, a-amylase has access to starch at this $\mathrm{pH}$ and catalyses the breakdown of this polysaccharide into monosaccharide and disaccharide. At a concentration of $100 \mu \mathrm{g} / \mathrm{mL}$, C. papaya leaf shows the highest percentage of inhibition of $25.2 \%$. There was a dose dependent increase in percentage inhibitory activity against a-amylase enzyme as shown in Table 2. From the data, the results suggest that the extract possesses significant inhibitory activity since the percentage inhibition varied from 19.63 to 25.2 in the concentration range of $80 \mu \mathrm{g} / \mathrm{mL}-100 \mu \mathrm{g} / \mathrm{mL}$ which was higher when compared to that of the standard drug within the same range. The a-amylase inhibitors act as an anti-nutrient that obstructs the digestion and absorption of carbohydrates (36).

Table 2. Effect of methanol extract of Carica papaya leaf on $\alpha$-amylase inhibition.

\begin{tabular}{ccc}
\hline $\begin{array}{c}\text { Concentration } \\
(\boldsymbol{\mu g} / \mathbf{m L})\end{array}$ & Standard & $\begin{array}{c}\text { Methanolic extract } \\
\text { of Carica papaya } \\
\text { leaf }\end{array}$ \\
\% Inhibition & Inhibition \\
\hline 20 & $5.65 \%$ & $9.6 \%$ \\
40 & $9.58 \%$ & $13.2 \%$ \\
60 & $13.20 \%$ & $16.54 \%$ \\
80 & $13.20 \%$ & $19.63 \%$ \\
100 & $22.50 \%$ & $25.2 \%$ \\
\hline Values are expressed as mean \pm SMD. Absorbance of blank $=0.217 \pm 0.00$
\end{tabular}

\section{Glucose uptake action of methanolic C.papaya extract}

Glucose transport across yeast cellular membrane occurs via facilitated diffusion down concentration gradient. The rate of glucose transport across the membrane in yeast cell system at different glucose concentrations, i.e. $20,40,60,80$, and $100 \mu \mathrm{g} / \mathrm{mL}$ respectively, is 
Ogundele et al., JOTCSA. 2017; 4(1): 99-114.

RESEARCH ARTICLE

presented in Table 3. The mechanism of glucose transport across the yeast cell membrane has been receiving attention as in vitro screening method for hypoglycaemic effect of various compounds present in medicinal plants. Recent studies on the transport of non metabolizable sugars and certain metabolizable glycosides suggest that sugar transport across the yeast cell membrane is mediated by stereospecific membrane carriers. This implies that the dosedependent increase in the glucose uptake of yeast (Table 3 ) is a reflection of the extract's ability to enhance the utilization of glucose by yeast. This is because transport of glucose is only attained (and continued) if there is removal of intracellular glucose. The result obtained suggest that methanol extract of $C$. papaya leaves were capable of enhancing glucose uptake (utilization) thereby controlling the blood glucose level (25).

Table 3. Effect of methanolic extract of Carica papaya leaf on the uptake of glucose by yeast cells.

\begin{tabular}{ll}
\hline Concentration $(\boldsymbol{\mu g} / \mathbf{m L})$ & Methanolic extract of Carica papaya leaf \\
\hline$\%$ Glucose uptake & \\
20 & $9.17 \%$ \\
40 & $16.2 \%$ \\
60 & $16.2 \%$ \\
80 & $19.3 \%$ \\
100 & $24.82 \%$ \\
\hline \multicolumn{2}{l}{ Values are expressed as mean \pm SMD. Absorbance of blank $=0.225 \pm 0.00$}
\end{tabular}

\section{In vitro non-enzymatic glycosylation of haemoglobin}

The inhibitory effect of methanolic C. papaya samples on non-enzymatic glycosylation of haemoglobin is shown in Table 4. C. papaya exhibits a concentration-dependent increase in \% inhibition of glycosylation, which suggests that the plant extract decreases the formation of the glucose haemoglobin complication and thus the amount of free haemoglobin increases. Interestingly, at a concentration of $100 \mu \mathrm{g} / \mathrm{mL}, C$. papaya showed the highest percentage inhibition of $20.6 \%$ which compared favorably with that of the standard. Increased concentration of glucose in the blood leads to its binding to haemoglobin which may result in the formation of the reactive oxygen species (37). 
Table 4. Effect of methanolic extract of $C$. papaya leaf extract on haemoglobin glycosylation.

\begin{tabular}{lll}
\hline Concentration $(\boldsymbol{\mu g} / \mathbf{m L})$ & $\begin{array}{l}\text { Standard } \\
\% \text { Inhibition }\end{array}$ & $\begin{array}{l}\text { Methanolic extract of Carica papaya leaf } \\
\% \text { Inhibition }\end{array}$ \\
\hline 20 & $5.38 \%$ & $5.38 \%$ \\
40 & $8.8 \%$ & $12.1 \%$ \\
60 & $17.8 \%$ & $15.2 \%$ \\
80 & $23.1 \%$ & $18 \%$ \\
100 & $29.7 \%$ & $20.6 \%$ \\
\hline
\end{tabular}

\section{CONCLUSION}

The result of the present study demonstrated that the qualitative phytochemical analysis of methanolic extract of $C$. papaya leaves confirmed the presence of the following phytoconstituents; polyphenol, tannins, saponins, terpenoids, flavonoids, glycosides, and alkaloids. The in vitro anti-diabetic potential of the plant extract was confirmed through $\alpha$ amylase inhibition, glucose uptake by yeast cells and non-enzymatic glycosylation methods. The result of this research confirms the claim of Yoruba herbalists in using the leaves of the plant to control diabetes, however; further exploration of the various bioactive compounds should be isolated and developed into drugs to combat the disease. The result of the present study confirmed that the methanolic extract of $C$. papaya leaves possess significant antidiabetic activity in vitro, this shows that the leaves has the potential for the development of drugs in combating diabetes.

\section{REFERENCES}

1. World Health Forum; Controller of Publication, United States of America, Ministry of Health Sciences forum, WHO, 1993;14(6): 390-396

2. Narkhede, M.B., Ajimire, P.V., Wagh, A.E., Manoj, M. and Shivashanmugam, A.T. In vitro antidiabetic activity of Caesalpina digyna (R.) methanol root extract. Asian J. Plant Sci. Res., 2011;1(2):101-106.URL:

https://www.researchgate.net/publication/266871671_In_vitro_antidiabetic_activity_of _Caesalpina_digyna_R_methanol_root_extract 
Ogundele et al., JOTCSA. 2017; 4(1): 99-114.

3. Polonsky, K.S.,. The past 200 years in diabetes. N. Engl. J. Med. 2012; 367, 13321340. DOI: $10.1056 /$ NEJMra1110560

4. DK Patel, SK Prasad, R Kumar, S Hemalatha.. An overview on antidiabetic medicinal plants having insulin mimetics property Asian Pac J Trop Biomed, 2012; 2 (4), pp. 320 330. DOI: $10.1016 / \mathrm{S} 2221-1691(12) 60032-\mathrm{X}$

5. Jung M, Park M, Lee HC, Kang YH, Kang ES, Kim SK. Anti-diabetic agents from medicinal plants. Curr med chem. 2006; 13(10): 1203-1218. URL:

https://www.ncbi.nlm.nih.gov/pubmed/16719780

6. Modak M, Dixit P, Londhe J, Ghaskadbi S, Paul A, Devasagayam T. Indian herbs and herbal drugs used for the treatment of diabetes. J. Clin Biochem Nutri. 2007; 40 (3): 163-173. DOI: $10.3164 /$ jcbn.40.163

7. Jarald E, Joshi SB, Jain DC. Diabetes and herbal medicines. Iran J Pharmacol Ther. 2008;7(1): 97-106. URL: http://ijpt.iums.ac.ir/index.php/ijpt/article/viewFile/369/331

8. Simon JE (1995). Basil New crop Factsheet Centre for New Crops and Plant Products, Purdue University. URL: http://

www.hort.purdue.edu/newcrop/CropFactSheets/basil.html.

9. Grover JK, Yadav S, Vats V. Medicinal plants of india with anti-diabetic potential. J Ethnopharmacol. 2002; 81: 81-100. DOI: 10.1016/S0378-8741(02)00059-4

10. Brai BIC, Odetola AA, Agomo PU. Anti-hyperglycemic activity of Cassia kleinii leaf extract in normal rats and alloxan-induced diabetic rats. Indian J. Pharmcol. 2007; 34: 409-415. URL: http://medind.nic.in/ibi/t02/i6/ibit02i6p409.pdf

11. Gondwe M, Okoro. PK, Juta R. Effect of diabetes on kidney. Diabetes.2008; 52: 283291

12. Ojiako AO, Chikezie PC, Ogbuji CA (2015) Blood glucose level and lipid profile of alloxan-induced hyperglycaemic rats treated with single and combinatorial herbal formulations J.Tradit Compl. DOI:10.1016/j.jtcme.2014.12.005 
13. Ojiako AO and Chikezie PC. Comparative proximate composition and hypoglycaemic properties of three medicinal plants (Verononia amygdalina, Azadirachata indica and Moringa oleifera). Pharmacogn commun .2014;4: 40-48. DOI:10.5530/pc.2014.3.4

14. Ugochukwu NH, Fafunso PJ, Boba AT, Babady NE. The various medicinal effects of Gongronema latifolium. Phytother Res.2005;12:46-52.

15. Ojewole JAO. Analgesic, anti-inflammatory and hypoglycaemic effects of Securidaca longepedunculata (Fresen.) [Polygalaceae] root-bark aqueous extracts inflammopharmacol. 2008;16: 174-181. DOI: 10.1007/s10787-007-0016-7

16. Ibegbulem CO, Chikezie PC. Hypoglycaemic properties of ethanolic extracts of Gongronema latifolium, Aloe perryi, Viscum album and Allium sativum administered to alloxan-induced diabetic albino rats (Rattus norvegicus). Pharmacogn commun.2013;3:12-16. DOI: 10.5530/pc.2013.2.4

17. Chikezie PC, Uwakwe AA. Activities of three erythrocyte enzymes of hyperglycaemic rats (Rattus norvegicus) treated with Allium sativa extract. J Diabetes Meta Discord.2014;13:50. DOI: 10.1186/2251-6581-13-50

18. Sathasivam K, Ramanathan S, Mansor S, Haris M, Wernsdorfer W."Thrombocytecount in mice after administration of papaya leaf suspension", The Middle European Journal of Medicine, 2009; 121(3), 19-22. DOI: 10.1007/s00508-009-1229-0

19. Yogiraj Vijay, Pradeep Kumar Goyal, Chetan Singh Chauhan, Anju Goyal, Bhupendra Vyas. Carica papaya Linn: An Overview. International Journal of Herbal Medicine, 2014;2 (5): 01-08 URL: http://www.florajournal.com/vol2issue5/jan2015/2-4-12.1.pdf

20. Adeneye, A.A., \& Olagunju, I.A. Preliminary hypoglycemic and hypolipidemic activities of the aqueous seed extract of Carica papaya Linn. in Wistar rats. Biology and Medicine.2009;1:1-10. DOI: http://www.biolmedonline.com/Articles/vol1_1_1-10.pdf

21. Ahmad, N., Fazal, H., Ayaz, M., Abbasi, B.H., Mohammad, I., Fazal, L.. Dengue fever treatment with Carica papaya leaves extracts. Asian Pac. J. Trop. Biomed.2011; 1:330333. DOI: $10.1016 / \mathrm{S} 2221-1691(11) 60055-5$ 
22. Owoyele, B.V., Adebukola, O.M., Funmilayo, A.A., Soladoye, A.O. Anti-inflammatory activities of ethanolic extract of Carica papaya leaves. Inflammopharmacol. 2008; 16: 168-173. DOI: $10.1007 /$ s10787-008-7008-0

23. Aruoma, O.I., Hayashi, Y., Marotta, F., Mantello, P., Rachmilewitz, E., Montagnier, L. Applications and bioefficacy of the functional food supplement fermented papaya preparation. Toxicology. 2010; 278: 6-16. DOI: 10.1016/j.tox.2010.09.006

24. William PJ, Douglas K. Extraction of plant secondary metabolites in natural products isolation. 2nd ed. Humana Press, New Jersey.2006;20: 323-35. DOI: 10.1385/159259-955-9:323

25. Gupta D, Kondongala S.C, Girish P. In vitro antidiabetic activity of pentacyclic tritrprnoida and fatty acid ester from bauhinia purpurea. Inter. J. Pharmacol. Pharmaceut. Tech.2013; Vol-2. ISSN-2277- 3436

26. Shekib L.A, Iraq E.I, Abo Baker S.M. "Studies on amylase inhibitors in some Egyptian legume seeds" Plant Foods Human Nutr; 1988;38, 325-332. DOI: 10.1007/BF01091730

27. Rajesh P. Dinesh Kumar Damiki Laloo, Siva Hemalatha. Evaluation of phytochemical and antioxidant activities of the different fractions of Hybanthus enneaspermus Linn $\mathrm{F}$ Muell Violaceae. Asian Pacific J of Tropical Medicine: 2009; 39:1-6. URL:www.journal homepage:www.elsevier.com/locate/apjtm

28. Akhila S., and N. G. Vijayalakshmi., "Phytochemical Studies On Carica Papaya Leaf Juice", IJPSR, 2015; 6 (2), 880883. DOI: 10.13040/IJPSR.0975-8232.6(2).880-83

29. Sheikh Fauziya and R Krishnamurthy. "Papaya (carica papaya): source material for anticancer", CIBTech Journal of Pharmaceutical Sciences, 2013;2(1), 25-34. URL: http://www.cibtech.org/cjps.htm.

30. Ayoola P.B. and A. Adeyeye. "Phytochemical and nutrient evaluation of Carica papaya (pawpaw) leaves",IJRRAS,2010;5(3),325-328.URL:

www.arpapress.com/Volumes/Vol5Issue3/IJRRAS_5_3_15.pdf. 
31. Baskaran C., V. Ratha bai, S.Velu, Kubendiran Kumaran. "The efficacy of Carica Papaya leaf extract on some bacterial and a fungal strain by well diffusion method", Asian Pacific Journal of Tropical Disease, 2012;2 (2), S658-S662 DOI: 10.1016/S22221808(12)60239-4

32. Okwu, D.E. and M.E. Okwu. Chemical Composition of Spondia Momb in plants J. Sustain. Agri. Environ., 2004;6: 140-147

33. Roman-Ramos, R., Flores-Saenz, J.L., and Alarcon-Aguilar, F.J. Anti-hyperglycemic effect of some edible plants. Journal of Ethnopharmacology.1995;48,25-32. URL: https://www.ncbi.nlm.nih.gov/pubmed/8569244

34. Megha G, Chaudhari Bhoomi B, Joshi Kinnari N, Mistry Brijesh Dabhi, Sanjay lal. In Vitro Antimicrobial Activity of Stem Bark of Bauhinia Purpurea. J Int Sci Press (India) 2013; 4:29-35. URL: https://www.researchgate.net/profile/Brijesh_Dabhi/publications

35. Rajbhar,K., Dawda, H. and Mukundan, U. Quantitative spectrophotometric estimation of specific monosaccharides by DNSA method. International journal of Research and Development Organization, 2016; 29(1):112-126. ISSBN: 2455-7676

36. Adesegun, S. A., Fayemiwo, O., Odufuye, B. Coker, H.A.B. a-amylase inhibition and antioxidant activity of Pterocarpus osun Craib. Journal of Natural Products, 2013; 6: 9095. URL: http://journalofnaturalproducts.com/Volume6/13_Res_paper-12.pdf

37. Clifford J.B, Caroline D. Review article: Traditional Plant Medicines as Treatments for Diabetes, Diabetes care.1989; 12(8). DOI: 10.2337/diacare.12.8.553. 
Türkçe Öz ve Anahtar Kelimeler

\section{Anti-Diabetic Efficacy and Phytochemical Screening of Methanolic Leaf Extract of Pawpaw (Carica papaya) Grown in North Central Nigeria.}

Ayorinde Victor Ogundele, Kabir Opeyemi Otun, Abdulfatai Ajiboye, Bolatito Eunice Olanipekun, Rasheed Bolaji Ibrahim

Öz: Carica papaya yaprak örnekleri (Yeşil) taze iken toplanmış ve altı tam gün kurutulmuştur. Yapraklar metanolle ekstrakte edilmiştir; elde edilen ekstraktlar standart bir prosedür kullanarak fitokimyasal içerik bakımından gözden geçirilmiştir. Fitokimyasal görüntülemeye göre tanenler, saponinler, terpenoidler, glikozidler ve alkaloidler gibi biyoaktif maddelerin varlığı ortaya konmuştur. Bitkinin in vitro antidiyabetik potansiyeli, geleneksel kullanımı doğrulamak amacıyla belirlenmiştir. Bu çalışmanın sonucuna göre C. papaya yapraklarının in vitro'da belirgin antidiyabetik aktivite gösterdiği ortaya konmuştur, buna göre, bitkinin yaprakları diyabetle savaşta kullanılabilecek ilaçların geliştirilmesi için potansiyele sahiptir.

Anahtar kelimeler: Carica papaya yaprakları; fitokimyasal görüntüleme; biyoaktif maddeler; anti-diyabetik maddeler; in-vitro inceleme.

Gönderme: 09 Agustos 2016. Düzenleme: 23 Eylül 2016. Kabul: 14 Ekim 2016. 
